\title{
Methods to Renovate Ayurveda Sastric Churna to Tablet Dosage Form
}

\author{
Amrutha Valli GV*, Aruna V and Gayathri R \\ Dr. JRK's research and Pharmaceuticals Pvt Ltd., India
}

Submission: March 20,2019; Published: April 04, 2019

*Corresponding author: Amrutha Valli GV, Dr. JRK's research and Pharmaceuticals Pvt Ltd., No.18 \& 19, Perumal koil street, Kunrathur, Chennai 600069, India

\begin{abstract}
The science of converting Sastric Ayurveda churna to tablet dosage form was extensively researched. The sastric form of Ayurveda churna is difficult to use by patients due to the coarse powder form as well as the high quantity to be cosumed per dose (2-4gm). In order to enhance the acceptance of Ayurveda churna by the modern world necessary change in presentation packaging is needed. The question of how to convert $2 \mathrm{gms}$ of churna to $500 \mathrm{mg}$ of tablet requires greater scientific investigations and understanding. We have used the extractive value as the key determining factor to convert sastric Ayurveda churna to tablet dosage form. Details are presented in the paper.
\end{abstract}

Keywords: Ayurveda tablet; Aswagandhadi churna; Sitopaladi churna; Hinguvastaka churna; Avipatti churna; Nimbadi churna; Siva nili churna Pushyanuga churna; Bhaskara lavana churna

\section{Introduction}

Ayurveda or knowledge of life is an extension of vedic way of life of our ancient sages and spiritual leaders. The Lord Dhanvantari is considered to be the god who gifted Ayurveda to humanity. Ayurveda in fact is considered as fifth Veda after Rig, Sama, Yagur and Atharvana Veda's. Ayurveda system predominantly emphasize upon the wellness, health, longevity and finally the eternal salvation of human soul and attainment of eternity. Therefore, preserving the health is the fundamental tenet of Ayurveda System of medicine. Although Ayurveda system is time tested and has surpassed all experimental science and remain as a glorious healing system. But in recent times, it suffers poor acceptance due to the primitive method of preparations followed. Further most of the products are crude and natural. The application of modern technology is necessary to 'pack and present' the Ayurveda drugs to the present world in order to increase the acceptance. However, such transformation should be done carefully in order to preserve the traditional and intuitive values of the system. Simultaneously the system also must be made acceptable to the modern world.

A thorough scientific understanding on the method of preparation and the presentation format of various Ayurveda drugs are essential and only than the 'native science' can be packaged and presented in modern format and can be made the glorious Ayurveda sytem as an eternal science of our spiritual masters. We Dr. JRK's Research and Pharmaceuticals Pvt Ltd., has been working for the last three decades to propagate the benefits of the Siddha system for the welfare of humanity. With that understanding, we have made several efforts to revitalize the sastric Ayurveda churna's through changing the dosage form from the existing polyherbal churna form to easily consumable tablet dosage form. We have adopted the use of extractive value to equate the dosage justification from churna to tablet. We believe that our earnest effort would revolutionize the acceptance of Ayurveda system by the world at large and our yeomen effort shall benefit the humanity at large.

\section{Materials and Methods (Table 1)}

\section{Calculation of extractive value of sastric Ayurveda drug [1-4]}

For the calculation of extractive value $5 \mathrm{gm}$ of the sample was weighed accurately and was treated with $100 \mathrm{ml}$ of absolute alcohol in a clean conical flask of $250 \mathrm{ml}$. the conical flask was covered and placed the mixture was kept in a rotary shaker at room temperature and was allowed to shake for $6 \mathrm{hrs}$. After 6 hours the mixture was allowed to stand stationary for another $18 \mathrm{hrs}$. Then the mixture was filtered, and the filtrate was evaporated. After complete evaporation of the solvent the residual extract was weighed accurately, and the percentage of extractive value was calculated by using the formula given below Extractive value $(\%)=$ Weight of Residue/ weight of sample $\times 100$

\section{Formulation of Tablet [5-12]}

The conventional tablet base (Micro Crystalline Cellulose, Poly vinyl pyrrolidone and Magnesium stearate) was used. According to the extractive value of different Sastric Ayurveda 


\section{Journal of Complementary Medicine \& Alternative Healthcare}

drugs, the tablet dosage form was prepared. For example, if the extractive value of Aswagandhadi choornam was $11 \%$ means, every $100 \mathrm{gm}$ would contain $11 \mathrm{gm}$ of extractable matter and the remaining portion would be fibers which in all likely hood may not have any therapeutic value. The therapeutic dosage

Table 1: The list of sastric churna studied.

\begin{tabular}{|c|c|c|c|}
\hline Product & Ingredients & Dosage & Reference \\
\hline \multirow{7}{*}{ Aswagandhadi churna } & Eclipta alba & \multirow{7}{*}{ 2-4gm per day } & \multirow{7}{*}{ [5] } \\
\hline & Mesua ferrea & & \\
\hline & Elleteria cardamomum & & \\
\hline & Piper nigrum & & \\
\hline & Piper longum & & \\
\hline & Zingiber officinale & & \\
\hline & Withania somnifera and Sugar & & \\
\hline \multirow{5}{*}{ Sitopladi churna } & Sugar & \multirow{5}{*}{ 2-4gm per day } & \multirow{5}{*}{ [6] } \\
\hline & Bambusa arundinacea & & \\
\hline & Piper longum & & \\
\hline & Elettaria cardamomum & & \\
\hline & Cinnamomum zeylanicum & & \\
\hline \multirow{8}{*}{ Hingvastaka churna } & Zingiber officinale & \multirow{8}{*}{ 2-4gm per day } & \multirow{8}{*}{ [7] } \\
\hline & Piper nigrum & & \\
\hline & Piper longum & & \\
\hline & Apium leptophyllum & & \\
\hline & Rock salt & & \\
\hline & Cumimum cyminum & & \\
\hline & Nigella sativa & & \\
\hline & Ferula Asafoetida & & \\
\hline \multirow{11}{*}{ Avipatti churna } & Zingiber officinale & \multirow{11}{*}{ 2-4gms per day } & \multirow{11}{*}{ [8] } \\
\hline & Piper nigrum & & \\
\hline & Piper longum & & \\
\hline & Cinnamomum zeylanicum & & \\
\hline & Cinnamomum tamala & & \\
\hline & Elettaria cardamomum & & \\
\hline & Cyperus rotundus & & \\
\hline & Embelia ribes & & \\
\hline & Phyllanthus emblica & & \\
\hline & Operculina turpethum & & \\
\hline & Sugar & & \\
\hline \multirow{9}{*}{ Nimbadi churna } & Andrographis paniculata & \multirow{9}{*}{ 2-4gms per day } & \multirow{9}{*}{ [9] } \\
\hline & Picrorhiza kurroa & & \\
\hline & Cyperus rotundus & & \\
\hline & Zingiber officinale & & \\
\hline & Piper nigrum & & \\
\hline & Piper longum & & \\
\hline & Wrightia tinctoria (seeds) & & \\
\hline & Plumbago zeylanica & & \\
\hline & Holarrhena antidysenterica & & \\
\hline
\end{tabular}

recommended for the Aswagandhadi choornam is $2 \mathrm{gm}$. It means the $2 \mathrm{gm}$ of Aswagandhadi will have $220 \mathrm{mg}$ of extractable matter of various herbs. The tablet formulation was made with $80 \mathrm{mg}$ of the extractable matter of Aswagandhadi choornam presented in either 250 or $500 \mathrm{mg}$ of the base. 
Journal of Complementary Medicine \& Alternative Healthcare

\begin{tabular}{|c|c|c|c|}
\hline Siva nili churna & Indigofera aspalathoides & 2-4gms per day & {$[10]$} \\
\hline \multirow{17}{*}{ Bhaskara Lavana Churna } & Common salt & \multirow{17}{*}{ 3-6gms per day } & \multirow{17}{*}{ [11] } \\
\hline & Black salt & & \\
\hline & Rock salt & & \\
\hline & Coriandrum sativum & & \\
\hline & Piper longum & & \\
\hline & Piper longum root & & \\
\hline & Nigella sativa & & \\
\hline & Cinnamomum tamala & & \\
\hline & Mesua ferrea & & \\
\hline & Abies webbiana & & \\
\hline & Solena amplexicaulis & & \\
\hline & Piper nigrum & & \\
\hline & Cumimum cyminum & & \\
\hline & Zingiber officinale & & \\
\hline & Punia granatum & & \\
\hline & Cinnamomum zeylanicum & & \\
\hline & Elettaria cardamomum & & \\
\hline \multirow{26}{*}{ Pushyanuga churna } & Cissampelos pareira & \multirow{26}{*}{ 2-4gms per day } & \multirow{26}{*}[12]{} \\
\hline & Syzygium cuminii & & \\
\hline & Mangifera indica & & \\
\hline & Bergenia ciliata & & \\
\hline & Beriberis aristata & & \\
\hline & Hibiscus sabdariffa & & \\
\hline & Salmalia malabarica & & \\
\hline & Rubia Cordifolia & & \\
\hline & Holarrhena antidysenterica & & \\
\hline & Crocus sativus & & \\
\hline & Aegel marmelos & & \\
\hline & Aconitum hetrophyllum & & \\
\hline & Symplocos racemosa & & \\
\hline & Pavonia odorata & & \\
\hline & Red ochre & & \\
\hline & Zingiber officinale & & \\
\hline & Madhuca indica & & \\
\hline & Vitis vinifera & & \\
\hline & Pterocarpus santalinus & & \\
\hline & Myrica esculenta & & \\
\hline & Oroxylum indicum & & \\
\hline & Wrightia tinctoria (seeds) & & \\
\hline & Hemidesmus indicus & & \\
\hline & Woodfordia fruticosa & & \\
\hline & Glycyrrhiza glabra & & \\
\hline & Terminalia arjuna & & \\
\hline
\end{tabular}




\section{Results}

Following table shows the extractive value of different Sastric Ayurveda drugs. The extractable matter present per $2 \mathrm{gm}$ of various Sastric Ayurveda drugs is also presented in the Table 2.

\section{Aswagandhadi choornam}

The extractive value of Aswagandhadi choornam was 11\%. The recommended dosage of Aswagandhadi choornam is $2 \mathrm{gm}$. In every 2grams of Aswagandhadi choornam will contain $220 \mathrm{mg}$

Table 2: Extractive value of various Sastric Ayurveda products. of the extractable matter. To the tablet base of 250 or $500 \mathrm{mg}$, $220 \mathrm{mg}$ of the extractable matter of Aswagandhadi choornam was incorporated and accordingly the tablet was made.

\section{Sitopaladi Choornam}

The extractive value of Sitopaladi choornam was $24 \%$. The recommended dosage of Sitopaladi choornam is $2 \mathrm{gm}$. In every 2 grams of Sitopaladi choornam will contain $480 \mathrm{mg}$ of the extractable matter. To the tablet base of 250 or $500 \mathrm{mg}, 480 \mathrm{mg}$ of the extractable matter of Sitopaladi choornam was incorporated and accordingly the tablet was made.

\begin{tabular}{|c|c|c|c|}
\hline S. No & Product & Alcohol extractive value (\%) & Quantity of extractable matter present per dosage (gm) \\
\hline 1 & Aswagandhadi churna & 11 & 0.22 per 2gm \\
\hline 2 & Sitopaladi churna & 24 & 0.48 per $2 \mathrm{gm}$ \\
\hline 3 & Hinguvastaka churna & 12 & 0.24 per $2 \mathrm{gm}$ \\
\hline 4 & Avipatti churna & 6 & 0.12 per $2 \mathrm{gm}$ \\
\hline 5 & Nimbadi churna & 23.47 & 0.469 per $2 \mathrm{gm}$ \\
\hline 6 & Siva nili churna & 3.2 & 0.064 per $2 \mathrm{gm}$ \\
\hline 7 & Pushyanuga churna & 3.5 & 0.07 per $2 \mathrm{gm}$ \\
\hline 8 & Bhaskara lavana churna & 14.4 & 0.432 per $3 \mathrm{gm}$ \\
\hline
\end{tabular}

\section{Hinguvastaka churna}

The extractive value of Hinguvastaka churna was $12 \%$. The recommended dosage of Hinguvastaka churna is $2 \mathrm{gm}$. In every 2grams of Hinguvastaka churna will contain $240 \mathrm{mg}$ of the extractable matter. To the tablet base of 250 or $500 \mathrm{mg}, 240 \mathrm{mg}$ of the extractable matter of Hinguvastaka churna was incorporated and accordingly the tablet was made.

\section{Avipatti churna}

The extractive value of Avipatti churna was 6\%. The recommended dosage of Avipatti churna is $2 \mathrm{gm}$. In every 2 grams of Avipatti churna will contain $120 \mathrm{mg}$ of the extractable matter. To the tablet base of 250 or $500 \mathrm{mg}, 120 \mathrm{mg}$ of the extractable matter of Avipatti churna was incorporated and accordingly the tablet was made.

\section{Nimbadi churna}

The extractive value of Nimbadi churna was $23.47 \%$. The recommended dosage of Nimbadi churna is $2 \mathrm{gm}$. In every 2 grams of Nimbadi churna will contain $469 \mathrm{mg}$ of the extractable matter. To the tablet base of 250 or $500 \mathrm{mg}, 469 \mathrm{mg}$ of the extractable matter of Nimbadi churna was incorporated and accordingly the tablet was made.

\section{Siva nili churna}

The extractive value of Siva nili churna was $3.2 \%$. The recommended dosage of Siva nili churna is $2 \mathrm{gm}$. In every 2 grams of Siva nili churna will contain $64 \mathrm{mg}$ of the extractable matter. To the tablet base of 250 or $500 \mathrm{mg}, 64 \mathrm{mg}$ of the extractable matter of Siva nili churna was incorporated and accordingly the tablet was made.

\section{Pushyanuga churna}

The extractive value of Pushyanuga churna was $3.5 \%$. The recommended dosage of Pushyanuga churna is $2 \mathrm{gm}$. In every 2 grams of Pushyanuga churna will contain $70 \mathrm{mg}$ of the extractable matter. To the tablet base of 250 or $500 \mathrm{mg}, 70 \mathrm{mg}$ of the extractable matter of Pushyanuga churna was incorporated and accordingly the tablet was made.

\section{Bhaskara lavana churna}

The extractive value of Bhaskara lavana churna was $14.4 \%$. The recommended dosage of Bhaskara lavana churna is $3 \mathrm{gm}$. In every 3 grams of Bhaskara lavana churna will contain $432 \mathrm{mg}$ of the extractable matter. To the tablet base of 250 or $500 \mathrm{mg}$, $432 \mathrm{mg}$ of the extractable matter of Bhaskara lavana churna was incorporated and accordingly the tablet was made.

\section{Discussion}

We have explored a great scientific possibility to revive, rejuvenate and revitalize the Ayurveda system with the help of modern science and technology. We took utmost care to preserve the 'native-ness' of Ayurveda system while presenting the system to the modern world in modern format so that the ancient tradition and modern science dangle together harmoniously and thus Ayurveda system gains greater acceptance. Aswagandhadi churna, Sitopaladi churna, Hinguvastaka churna, Avipatti churna, Nimbadi churna, Siva nili churna, Pushyanuga churna and Bhaskara lavana churna are considered to be sacred Ayurveda drugs and are known to possess multipolar therapeutic benefits. Starting from providing health through improving digestion, appetite and assimilation to boost the immunity to cure certain 
diseases are the attributes of the above Ayurveda drugs. However, the acceptance of the above recipes is highly limited to geriatric age group and those who suffer from various non-communicable diseases. Popular acceptance to all the above Siddha recipes is relatively poor.

All the above Ayurveda drugs are formulated in churna form where the different herbs are pulverized and then mixed together and then is prescribed to the patient. Consumption of $2 \mathrm{gm}$ of the crude herbal powder (the above recipes) is quite difficult and hence most patients seldom use these products. The issue of non-compliance due to the method of presentation i.e., crude mix greatly limit the acceptance of Ayurveda system and thereby Ayurveda system failed to gain appreciation from humanity and also the benefits of Ayurveda system to the humanity could not fully blossom. The Ayurveda drugs unless and until prepared, packed and presented in the most acceptable form, the Ayurveda system cannot be made glorious, nor the humanity would benefit from the Ayurveda system. A real tribute to the Ayurveda system lies in revitalizing the ancient concepts and recipes and presenting them in the modern format without losing the sanctity and sacredness Ayurveda system that was gifted to mankind by the Dhanvantari. We have used the extractive value to convert the above Ayurveda drugs to tablet dosage form. A careful analysis of different Ayurveda drugs has given us two dimensions of understanding viz., extractable constituents that was present and the residual base or vehicle. In the case of Aswagandhadi choornam, it contains $11 \%$ of extractable matter. The balance $96 \%$ was herbal fiber and may not have any therapeutic value except acting as vehicle or base. So the real therapeutic benefit of Aswagandhadi choornam was achieved only from the $11 \%$ of the extractable matter that is present. We have extracted the extractable matter and separated it from the herbal base. The extractable matter was reconstituted with the conventional tablet base at $11 \%$ and thereby we ensured that every 250 or $500 \mathrm{mg}$ tablet of Aswagandhadi choornam is equivalent to $2 \mathrm{gm}$ of Aswagandhadi choornam in churnam form. The same method we followed for formulating all other sastric siddha recipes such as Sitopaladi churna, Hinguvastaka churna, Avipatti churna, Nimbadi churna, Siva nili churna, Pushyanuga churna and Bhaskara lavana churna but the extractive value of the respective recipe was used for the tablet formulation. Tablet dosage form is one of the most accepted drug dosage forms followed worldwide. The tablet base is composed of Microcrystalline cellulose which can be equated to the herbal fibers present in most of the siddha churna. However, Microcrystalline cellulose has got great compressibility which the herbal fibers lack greatly. Another advantage of Microcrystalline cellulose is that when the extractable matter is incorporated in the above base it would get released instantaneously whereas such spontaneous release of extractable matter from the respective herbal sources is not that easy. Therefore, the tablet dosage form of all the sastric drugs are likely to offer faster therapeutic delight than when they are prescribed in the native form i.e., churna. We have attempted not only to present the sastric Ayurveda drugs in modern format but also worked hard to enhance the therapeutic benefit.

Patients mustfind the therapeutic benefitas quicklyas possible and only than such recipes will be accepted by modern world and not just when they are presented in modern format alone. The licensing authorities must encourage, support and promote the modern methodologies and technologies to reformulate and present the siddha recipes to galvanize its acceptance and to gain siddha system a 'leader in health care' stature at global level. The native thoughts, concepts, ethos, beliefs, practices and drugs must be preserved while modernizing and only then Ayurveda system shall remain as Ayurveda system that was gifted to mankind by Dhanvantari and at the same time and the system also would look modern, scientific and acceptable. Dr. JRK's Research and Pharmaceuticals is a forerunner in popularizing the sastric system of the medicine, through advanced science and alleviating wide spectrum of agony and sufferings of humanity through Ayurveda and siddha treatment. The transformation of Ayurveda sastric churna to tablet dosage form would certainly enhance the scientific credence of the immortal, time tested healing practice - Ayurveda system of medicine.

\section{References}

1. Kadam DK, Ahire PD, Bhoye JV, Patil AR, Yadav DK (2018) Comparative standardization study of three triphala churna formulation. International Journal of Pharmacognosy 6(1).

2. Sane RT (2002) Standardization, quality control and GMP for herbal drug. Indian drugs 39(3): 184-190.

3. Khandelwal KR (2011) Practical Pharmacognosy, Techniques and Experiments, Nirali Prakashan, $20^{\text {th }}$ (edn.).

4. WHO (2002) Quality Control Methods for Medical Plants Materials, ATTBS Publisher: 65-67.

5. Nishteswar K, Vidyanath R (2011) Sahasrayogam $3^{\text {rd }}$ (edn), Chowkhamba Sanskrit series office, Varanasi, pp. 205-206.

6. Nishteswar K, Vidyanath R (2011) Sahasrayogam $3^{\text {rd }}$ (edn), Chowkhamba Sanskrit series office, Varanasi, pp. 165-166.

7. Ayurvedic formulary of India-Part-1: 353

8. Nishteswar K, Vidyanath R (2011) Sahasrayogam $3^{\text {rd }}$ (edn), Chowkhamba Sanskrit series office, Varanasi, pp. 200.

9. Nishteswar K, Vidyanath R (2011) Sahasrayogam $3^{\text {rd }}$ (edn), Chowkhamba Sanskrit series office, Varanasi, pp. 190.

10. Ayurveda pharmacopoeia of India 6: CLXXXIV.

11. Ayurvedic formulary of India-Part-1,7:27.

12. Nishteswar K, Vidyanath R (2011) Sahasrayogam $3^{\text {rd }}$ (edn), Chowkhamba Sanskrit series office, Varanasi, pp. 172-173. 


\section{Your next submission with Juniper Publishers will reach you the below assets}

- Quality Editorial service

- Swift Peer Review

- Reprints availability

- E-prints Service

- Manuscript Podcast for convenient understanding

- Global attainment for your research

- Manuscript accessibility in different formats ( Pdf, E-pub, Full Text, Audio)

- Unceasing customer service

Track the below URL for one-step submission https://juniperpublishers.com/online-submission.php 